\title{
Clarice Lispector e a contracena da história em "A Hora da Estrela"
}

\section{Clarice Lispector and the historical context in "A Hora da Estrela"}

\author{
Isabel Virginia de Alencar Pires ${ }^{1}$
}

\begin{abstract}
Resumo
Este artigo aborda o livro A hora da estrela, de Clarice Lispector, à luz dos pressupostos da Teoria da Recepção, de Jauss, que leva em conta o contexto histórico nas análises literárias. Publicada em fins de 1977, essa obra - que conta a história de Macabéa, uma nordestina que, "sem saber como nem por que", acaba indo morar no "inacreditável Rio de Janeiro" - é considerada por diversos estudiosos como a "mais explicitamente social" da autora, pois até então os livros clariceanos costumavam ser recorrentemente acusados pela crítica da época de se "alhearem" da realidade, dedicando-se predominantemente a abordagens de caráter psicológico e deixando de lado o contexto político e social. Em A hora da estrela, a temática social passa a ser mais explícita, verificando-se assim uma espécie de "ruptura" na trajetória literária clariceana, interrompida no mesmo ano de publicação da obra, com a morte da autora. Este artigo busca apreender, nas entrelinhas do texto, as marcas que o diálogo do último livro lançado em vida pela escritora, durante o período do autoritarismo brasileiro, realiza com o seu contexto de surgimento. Para tanto, o estudo faz ainda uma aproximação entre o último livro de Clarice Lispector e o cinema de Glauber Rocha.
\end{abstract}

Palavras-chave: História e ficção. Literatura do período autoritário brasileiro. Literatura de Clarice Lispector.

\begin{abstract}
This article contemplates Clarice Lispector's "A hora da estrela" (The Hour of the Star), based on Jauss' Reception Theory, which takes into account the historical context in literary analyses. Published in late 1977, this work - which tells the story of Macabéa - a natural born northeast Brazilian woman that "not knowing why or how" moves to the "unbelievable city of Rio de Janeiro" - is considered by many scholars the "most explicitly social" one done by the author. Up to that moment, her books had frequently been accused by critics of "deviating" from reality, focusing predominantly on psychological features and leaving social and political contexts aside. In "A Hora da Estrela", the social themes become more explicit, representing a kind of "rupture" in the writer's literary career, which was interrupted by her death, the same year of its publication. The article is an attempt to apprehend traces of the dialogic relation between the writer's last work, before her death, and its context, which includes the period of dictatorship in Brazil. In order to do that, this study also makes a comparison between the book and the film version, directed by Glauber Rocha.
\end{abstract}

Keywords: History and Fiction. Brazilian literature during dictatorship years. Clarice Lispector's Literature.

\footnotetext{
1 Mestre em Literatura Brasileira pela UERJ com graduação em Ciências Sociais pela UFMG; trabalha no Instituto de Pesquisa Econômica Aplicada (IPEA), tendo atuado como revisora de livros e periódicos publicados por esse órgão. Pesquisa os seguintes temas: Romantismo no Brasil, Machado de Assis, ceticismo e metodologia cética, e ainda literatura brasileira do período autoritário, tendo publicado, sobre este último tema, o ensaio "Glauber Rocha e Rubem Fonseca: um novo modo de produzir cinema e literatura no Brasil" na revista Línguas e letras, vol. 6, n. 11, 2 sem./2005. Também possui trabalhos publicados em periódicos acadêmicos sobre Machado de Assis e o ceticismo metodológico.
} 


\section{Introdução}

Gafe é a hora em que certa realidade se revela. (Clarice Lispector)

Clarice Lispector inicia sua obra em 1940, quando a escritora publica o primeiro conto, "Triunfo", em 25/05/1940, no semanário Pan, de Tasso da Silveira. Logo se seguiram outros contos, publicados esporadicamente em jornais, alguns deles reunidos depois em coletâneas, como Alguns contos (1952) e Laços de família (LISPECTOR, 1960/1983). Em 1944, vem à luz o seu primeiro romance, Perto do coração selvagem (LISPECTOR, 1990), que lhe rendeu o prêmio Graça Aranha e que mereceu de Antonio Cândido o seguinte comentário: "A intensidade com que sabe escrever e a rara capacidade da vida interior poderão fazer desta jovem escritora um dos valores mais sólidos e, sobretudo, mais originais da nossa literatura, porque esta primeira experiência já é uma nobre realização." (CÂNDIDO, 1977, p. 131).

Será precisamente este primeiro romance clariceano que irá inaugurar, na literatura brasileira, uma nova vertente, oposta a tudo o que se fazia até então. De caráter essencialmente experimentalista, desprezando as convenções literárias consagradas de espaço e tempo, o livro de estreia de Clarice Lispector "propiciava uma tensão psicológica poucas vezes alcançada na literatura da época." (ROCHA, 2003, p. 48). Nesta "aula inaugural", como observa Silviano Santiago (apud ROCHA, 2003, p. 48), "a literatura é literatura - eis a fórmula mais simples e mais enigmática para apreender o sentido" da proposta literária da nova escritora, que buscava, sobretudo, a "experiência interior", o "aprofundamento introspectivo", e os "labirintos mais retorcidos da mente", nas palavras de Antonio Cândido (1977).
Constituída de contos, crônicas, romances, livros infantis, entrevistas realizadas com personalidades públicas - resultantes da sua atividade de jornalista -, e até um esboço de peça teatral, ${ }^{2}$ além de algumas traduções, a obra de Clarice Lispector atravessa quatro décadas, finalizando-se em 1977, quando morre a escritora e quando é publicado o livro A hora da estrela. Essas quatro décadas em que produz Clarice Lispector coincidem com períodos extremamente críticos da história brasileira. Surgida em pleno Estado Novo de Getulio Vargas, a obra clariceana se desenvolve durante o conturbado segundo governo Vargas, a crise política que sucedeu o governo JK e a implantação do regime de ditadura militar no Brasil, a partir de 1964. Registrese ainda a ocorrência da Segunda Guerra Mundial, cujos reflexos a escritora vivenciou de bem perto, uma vez que, entre 1944 e 1949, residiu em Nápoles, na Itália, e em Berna, na Suíça, acompanhando o marido diplomata, e onde escreveu os romances $\mathrm{O}$ lustre (1946) e A cidade sitiada (1949).

Embora tenha sido gerada em períodos bastante conturbados, a obra de Clarice Lispector, como chama a atenção Rafael Batista de Sousa (2008, p. 282), foi considerada recorrentemente pela crítica de sua época como "alienada dos problemas sociais brasileiros e das questões sócio-políticas de seu tempo." Críticos como Alfredo Bosi, Nelson Werneck Sodré, Roberto Schwarz e Celso Pedro Luft veem na abordagem existencial e no caráter introspectivo da narrativa, fortemente presentes desde o seu primeiro romance, a "razão de ser" dos textos clariceanos, ou seja, aquilo que constituiria o "projeto literário" da escritora (COUTINHO, 1986). Apenas recentemente essa visão começou a mudar, com o surgimento de estudos que contemplam o diálogo da obra clariceana com o contexto histórico, como os ensaios reunidos em coletânea organizada

\footnotetext{
2 A pecadora queimada e os anjos harmoniosos, publicada na primeira edição de A legião estrangeira (1964) sob o título de "Fundo de gaveta".
} 
por André Luís Gomes (2008). Desse modo, os textos clariceanos, que costumavam ser vistos como pertencentes exclusivamente ao campo da "literatura psicológica", começam a ser analisados segundo uma nova percepção, que considera os aspectos sociais aí presentes.

Sousa (2008, p. 286), por exemplo, analisa, no romance clariceano A paixão segundo G. H. (1964), o seu conteúdo social, representado pelo confronto estabelecido entre a patroa G. H. e a empregada ausente, Janair, concluindo que as leituras que se fizeram privilegiando, na literatura de Clarice Lispector, o intimismo, o estilo, a estrutura, o aspecto filosófico, etc, "cooperam no sentido de impedir uma análise comprometida com a questão social, uma vez que havia já uma imagem consolidada da escritura da autora, que, ao que se acreditava em larga escala, não ficcionalizava a sociedade brasileira em suas maiores fraturas, não tratava de assuntos que pudessem dá-la o caráter de escritora engajada.". De outro lado, Ana Carolina de Araújo Abiahy (2008), ao analisar os contos "A fuga" (publicado em jornal em 1941 e na coletânea póstuma $A$ bela e a fera, de 1979), "A imitação da rosa", do livro Laços de família (LISPECTOR, 1960/1983), e “Amor", publicado na coletânea Alguns contos (1952), verifica uma tendência da crítica literária em considerar os contos de Clarice Lispector que tratam da vida privada e focalizam as angústias individuais das personagens como desvinculados de qualquer conflito de ordem social, ou seja, do seu contexto histórico. No entanto, para a ensaísta, seria justamente o contrário, uma vez que, nos contos analisados, as protagonistas retratam mulheres imersas num universo doméstico idealizado pela ideologia patriarcal dos contextos históricos a que os contos pertencem. Assim, a crítica acabaria por "neutralizar" a produção textual da escritora, tomando-a como um "sujeito teoricamente neutro" (GOMES, 2008, p. 29).
Contrariando o "horizonte de expectativa" (JAUSS, 1994, p. 28) da crítica literária de sua época, que esperava não somente uma escrita de moldes realistas, mas principalmente textos politicamente engajados, a obra clariceana certamente possui uma mensagem mais sutil e delicada, que apenas recentemente vem despertando interesse, e que deve ser apreendida antes nas "entrelinhas" do texto, como adverte a própria escritora em Água viva (1973): "Então escrever é o modo de quem tem a palavra como isca: a palavra pescando o que não é palavra. Quando essa não palavra - a entrelinha morde a isca, alguma coisa se escreveu. Uma vez que se pescou a entrelinha, poder-se-ia com alívio jogar a palavra fora." (LISPECTOR, 1980, p. 21).

Publicada em fins de 1977, A hora da estrela ${ }^{3}$ - que conta a história de Macabea, uma nordestina que, "sem saber como nem por que", acaba indo morar no "inacreditável Rio de Janeiro" - é considerada por diversos estudiosos como a obra "mais explicitamente social" da autora. Ao contrário das obras anteriores, acusadas pelos críticos da época de se "alhearem" da realidade, dedicadas quase que exclusivamente, segundo eles, a abordagens de caráter psicológico, em que o contexto político e social era deixado de lado, em $A H E$, a temática social passa a ser explicitamente abordada, provocando assim uma espécie de "ruptura" na trajetória literária clariceana, infelizmente interrompida no mesmo ano de publicação da obra, com a morte da autora.

Este estudo faz uma abordagem de $A H E$, de Clarice Lispector, seguindo a linha de investigação que relaciona a obra literária com o seu contexto de surgimento, buscando contribuir assim para uma visão renovada da obra de Clarice Lispector, que a afaste da imagem de escritora "alienada" dos problemas do seu tempo, ao passo que se propõe recuperar um aspecto pouco explorado na obra clariceana. Desse modo, a presente análise lança mão do pressuposto básico da Teoria da Recepção,

${ }^{3}$ Denominado doravante AHE. 
de Hans-Robert Jauss (1994), que leva em conta a importância do contexto histórico na produção e recepção de uma obra literária. Valendo-se ainda do conceito de "fratura formal" de Adorno (1985) segundo o qual toda obra de arte, independentemente das intenções e da origem social do seu autor, reflete as antinomias e antagonismos da sociedade, sendo possível assim vislumbrar, na própria obra, as marcas deixadas pelo contexto em que ela surge -, este artigo busca "pescar" nas entrelinhas do texto, à maneira clariceana, o diálogo do último livro lançado em vida pela escritora, durante o período do autoritarismo brasileiro, com o seu contexto de surgimento. Para tanto, o estudo apresenta, na seção seguinte, uma análise das principais técnicas literárias empregadas por Clarice Lispector ao longo de sua obra, e de que modo essas técnicas são aproveitadas em $A H E$, passando depois, na seção 3, à análise de um possível diálogo entre o último livro publicado em vida pela escritora e seu contexto de surgimento. Uma breve conclusão encerra o estudo.

\section{As Técnicas Narrativas Clariceanas em A "Hora da Estrela"}

O "romance mais nitidamente social de Clarice" (SPINELLI, 2008, p. 97) apresenta uma dupla temática: a temática social, explicitada por meio da personagem Macabéa e seu namorado, Olímpico de Jesus, e a temática por assim dizer "intelectual", acerca do próprio trabalho do escritor, apresentada por meio do personagem Rodrigo S. M., "autor" que discute o trabalho de feitura de sua própria obra e que, para muitos estudiosos, se constituiria mesmo na parte mais representativa da obra.

AHE se pretende, pois, uma narrativa escrita pelo personagem Rodrigo S. M., que se identifica como um "escritor fracassado", mas sobre quem pouco se sabe, a não ser que gosta de "vinho branco gelado" e que necessita "se por ao nível da nordestina" para contar, de forma pouco ortodoxa, o dia-a-dia de Macabéa, uma "nordestina perdida no Rio de Janeiro". Esse artifício literário também foi utilizado por Clarice Lispector em Um sopro de vida (publicação póstuma, 1978), em que o personagem Autor dá vida à personagem Ângela Pralini, espécie de "consciência inconsciente", já que o Autor sabe de sua existência, mas Ângela Pralini ignora por completo esse que seria a sua "outra metade".

Exibindo marcas de diversos tipos e influências, $A H E$ pode ser considerada ainda uma obra de difícil filiação estética. Ao mesmo tempo em que dá continuidade a algumas técnicas narrativas já utilizadas pela escritora em outras obras, lança mão de novas técnicas ou de técnicas pouco usuais nos textos anteriores. A seguir, o trabalho enfoca algumas das técnicas clariceanas empregadas pela escritora em obras anteriores - como a epifania, a metalinguagem e o pastiche -, apresentando o modo como se dá o aproveitamento dessas técnicas em AHE.

\section{A "epifania"}

Segundo o conceito forjado por Afonso Romano de Sant'Anna (1973, 1988), a epifania, ou "momento de revelação existencial", consistiria num ato de "conhecimento repentino da verdade" pelo qual passam as personagens clariceanas, sempre a partir de um fato corriqueiro, um instante comum - o "instante-já"4 -, que tem, porém, o poder de desencadear o "fluxo da consciência". Para Olga de Sá (2000), a epifania é um tema recorrente na obra clariceana, constituindo-se mesmo como um "procedimento de escrita", e não apenas como uma técnica, tema ou motivo. Exemplos dessa "epifania" clariceana podem ser encontrados em três textos, escritos em épocas distintas, descritos sucintamente a seguir.

4 Essa expressão, utilizada por Clarice Lispector no romance Água viva (1973), foi apropriada pelos estudiosos da "epifania" clariceana com o objetivo de exemplificá-la. 
No conto "Amor", da coletânea Alguns contos (1952), republicado em Laços de família (LISPECTOR, 1960/1983), a visão de um cego mascando chicletes na rua revela para a dona-de-casa Ana a "cegueira" em que ela até então se encontrava quanto à sua condição social e familiar - o que a leva a passar uma tarde no Jardim Botânico, onde ela enxerga a natureza de forma distorcida, enquanto faz suas reflexões, cercada por sacolas de compras de supermercado. No romance $A$ paixão segundo $\mathrm{G}$. H. (1964), a epifania da personagem-narradora se dá quando G. H., uma escultora de classe alta, decide limpar a cobertura em que vive "em semiluxo" e, ao ver uma caricatura sua, feita a carvão pela empregada que se havia demitido no dia anterior, depara-se com a necessidade de realizar uma espécie de autopurificação - fato que a leva a ingerir, numa espécie de "paródia" do ritual de comunhão da hóstia católica, a massa branca de uma barata esmagada pela porta do armário no quarto de empregada. No conto "A procura de uma dignidade" (da coletânea Onde estiveste de noite, de 1974), a epifania ocorreria quando a personagem, a $\mathrm{Sr}^{\mathrm{a}}$ Jorge B. Xavier, uma mulher em torno de 70 anos, perde-se casualmente nos subterrâneos do estádio do Maracanã, sem conseguir achar a saída, e percebe a falta de sentido de sua própria vida, seu vazio existencial e sua anulação como pessoa, simbolizada pela "máscara" social atrás da qual se esconde - o nome do marido -, descoberta que a leva a cometer suicídio.

Rompendo com os pressupostos do "bem escrever”, baseados em princípio-meio-fim, a "epifania" clariceana constituiria a matéria-prima de uma "anti-literatura", que vários estudiosos reconhecem ser a "marca por excelência" dos textos de Clarice Lispector. Para Afonso Romano de Sant'Anna, a recorrência de um "ritual epifânico" nos textos clariceanos geraria o "anti-romance com anti-personagens numa anti-língua" (SANT'ANNA, 1988). Assim, a utilização da técnica da "epifania" seria precisamente a responsável por interpretações que consideram a literatura clariceana não como "espelho" das circunstâncias econômicas, políticas ou sociais, mas "espelho da mente, registrado através do fluxo da consciência, que indefine as fronteiras entre a voz do narrador e a das personagens" (CAMPEDELLI; ABDALA JUNIOR, 1981, p. 103), reforçando deste modo o caráter introspectivo das narrativas clariceanas, acusadas frequentemente de se alhearem da "realidade".

Segundo Rafael Batista de Sousa (2008, p. 282), a imagem de "escritora alienada" de Clarice Lispector "ganhou forças com as críticas que recebeu no Pasquim (1972, $n^{\circ} 138$ ), [em que a escritora é retratada numa charge] sendo enterrada no Cemitério dos Mortos-Vivos do Cabocô Mamado, personagem do cartunista Henfil, em que aparece como 'uma simples cronista da flor, dos pássaros, das gentes, da beleza de viver', que lava as mãos diante do caos social". Assim, Clarice Lispector passou a ser considerada comumente, e não apenas pela crítica especializada, uma "autora, que, ao que se acreditava em larga escala, não ficcionalizava a sociedade brasileira em suas maiores fraturas, não tratava de assuntos que pudessem dá-la o caráter de escritora engajada" (GOMES, 2008, p. 286). Na via oposta, AHE costuma ser ressaltado como "o romance social" de Clarice Lispector, que teria "traído" sua própria obra. No entanto, essa visão também deve ser tomada com cuidado, dada a complexidade deste texto clariceano, que a aparente singeleza da narrativa esconde, pois, embora o aspecto social esteja de fato aí tematizado, o livro não se restringe somente a essa questão.

Ao contrário das concepções "intimistas" da efipania presente na obra de Clarice Lispector, que a veem como desvinculada da "realidade", Vicentini (2008, p. 26)a considera como pequenas histórias, triviais, individuais, que tornam os personagens clariceanos espectadores da História. Assim, para Vicentini, a epifania dos personagens clariceanos corresponderia à "História que nos é dada, que podemos viver. A grande História segue impune e inexorável", pois a participação nela de pessoas comuns "não acontece, termina por ser eternamente adiada". 
Aqui, consideramos que a "epifania" clariceana identifica-se precisamente com a realidade, na medida em que apresenta-se tão imprevisível quanto esta - evidentemente, não considerada sob o prisma do Realismo, o movimento literário e artístico baseado no cânone positivista que dominou toda a segunda metade do século XIX e que tinha a pretensão de copiar "fielmente" as mazelas sociais, explicando-as mediante relações de causalidade com fatores ambientais, climáticos e de raça. Ou seja, a epifania clariceana, fugindo a uma escrita pretensamente "realista" - isto é, fabricada dentro de parâmetros "naturalizados" do Realismo -, se aproximaria paradoxalmente da própria realidade: aquela a que Machado de Assis parece se referir, quando afirma, no ensaio "A nova geração" (1879), que "a realidade é boa, o realismo é que não presta para nada".

Em $A H E$, é justamente a "realidade" o mote para a "epifania" do narrador/escritor Rodrigo S. M.: "Transgredir, porém, os meus próprios limites me fascinou de repente. E foi quando pensei em escrever sobre a realidade, já que essa me ultrapassa. Qualquer que seja o que quer dizer 'realidade." (LISPECTOR, 1998a, p. 17). Desse modo, Rodrigo S. M. também possuiria o seu "ritual epifânico", passando pela descoberta súbita de que necessita "escrever sobre a realidade", a partir de um "fato banal", vivido por ele como um "instantejá": "É que numa rua do Rio de Janeiro peguei no ar de relance o sentimento de perdição no rosto de uma moça nordestina. Sem falar que eu em menino me criei no Nordeste" (LISPECTOR, 1998a, p. 12).

No último texto publicado em vida por Clarice Lispector, o aproveitamento da técnica da "epifania" se faz com uma dupla função: ao mesmo tempo em que desencadeia a consciência do escritor quanto ao objeto narrado (a "realidade", que lhe surge sob a aparência da nordestina Macabéa), também tem o poder de desencadear a consciência de Rodrigo S. M. enquanto sujeito narrador, levando-o a uma espécie de crise existencial que coloca em xeque a relevância mesma de sua atividade para a sociedade
- “Aliás - descubro eu agora - também eu não faço a menor falta, e até o que escrevo um outro escreveria" (LISPECTOR, 1998a, p. 15) -, numa dolorosa constatação de que o "viver à toa" da datilógrafa Macabéa encontra ressonâncias no ofício (dispensável, talvez) do intelectual brasileiro: "Para que eu escrevo? E eu sei? Sei não" (LISPECTOR, 1998a, p. 36).

\section{A metalinguagem}

A metalinguagem, que, segundo alguns estudiosos, seria o "ponto forte" do projeto literário de Clarice Lispector, apresenta-se na obra clariceana sob dois aspectos: como experimentação linguística e como discussão sobre o papel do escritor e sua elaboração ficcional. Como observa Maria Estela Lima (2008), em Uma aprendizagem ou o livro dos prazeres (1969), a narrativa, começando com uma vírgula e terminando com dois pontos, é entremeada por parágrafos terminados com vírgulas, travessões ou mesmo sem pontuação alguma, que serviriam para exprimir a variação psicológica da personagem Loreley. Em Água viva (1973), a atividade de pensar o próprio ato de escrever torna-se "matéria prima na construção do texto, entremeando-o como uma espécie de pano de fundo" (VASCONCELLOS, 2008, p. 232), utilizada para discutir o ofício do escritor. Nos contos de $A$ via crucis do corpo (1974), também se observa igual discussão do trabalho do escritor e seu lugar na sociedade, pois, neste livro, “a palavra está no embate com as suas possíveis caricaturas: o clichê, o kitsch, a estereotipia, a adequação às 'forças desejantes' do mercado" (FRANCO JUNIOR, 2008, p. 42).

Clarice Lispector publicou boa parte de sua obra ${ }^{5}$ durante o período autoritário brasileiro, que durou de abril de 1964 a março de 1985, quando um civil - José Sarney - assume finalmente a presidência da República, substituindo Tancredo Neves, eleito em janeiro de 1985 pelo voto indireto do colégio eleitoral e afastado por problemas de saúde, que culminaram em sua morte, em 21/04/1985. A ditadura militar 
brasileira caracterizou-se pela arbitrariedade, pela supressão das liberdades constitucionais e pela extrema violência institucional, assegurados por uma série de mecanismos "legais": 17 "Atos Institucionais" e seus 104 "Atos Complementares", promulgados entre 30/10/1969 e 15/03/1974, dos quais o AI-5, publicado em 13/12/1968, uma sexta-feira, representou, como observa Salvador Werneck Vianna, uma "violenta radicalização" e endurecimento do regime:

O AI-5 deu origem, em etapas distintas, a mais 12 atos institucionais (todos editados por Costa e Silva e pela junta militar que o sucedeu), 59 atos complementares e oito emendas constitucionais, abrangendo todas as áreas da vida nacional. Tornando plena a legislação de exceção, os governos militares puderam assim usar rotineiramente o poder coercitivo como alternativa para superar os conflitos políticos (VIANNA, 2007, p. 215).

Nesse contexto de repressão institucionalizada, a censura, fortemente imposta aos meios de comunicação, irá provocar, na década de 1970 no Brasil, o surgimento da chamada "literaturareportagem", que abria espaço à denúncia, tornando-se "porta-voz" dos problemas sociais e políticos e "preenchendo espaços jornalísticos, já que a imprensa, então amordaçada pela censura, deixava vácuos de informação" (BARBIERI, 2003, p. 81). Os livros Zero (1975), de Ignácio Loyola de Brandão, Feliz Ano Novo (1975), de Rubem Fonseca, e O que é isso, companheiro? (1979), de Fernando Gabeira, seriam exemplos desse tipo de literatura, que questionava os valores de uma sociedade assentada sobre bases políticas e econômicas perversas, em que a alta concentração de renda provocava o aumento da exclusão social. ${ }^{6}$ Clarice Lispector, no entanto, parece se situar na contracorrente dessa tendência, pois, embora tenha participado da Passeata dos Cem Mil contra o regime militar, em 26/06/1968, seus textos não são "porta-voz" de discursos politizados, levando às seguintes questões: o uso da metalinguagem por Clarice, no contexto de ditadura militar, teria como intuito o não enfrentamento das questões políticas e sociais que então se colocavam, ou a metalinguagem remete à tentativa de reafirmar o projeto literário que a escritora inaugurara na literatura brasileira, baseado na temática intimista e na experimentação linguística e formal?

Em $A H E$, observa-se a ocorrência do tipo de metalinguagem que faz reflexões acerca do trabalho do escritor, pontuando toda a narrativa com questionamentos referentes à atividade intelectual e ao fazer literário. Assim, como observa Fátima Cristina Rocha, "rivalizando com Macabéa pelo primado da narrativa, avulta o personagem narrador Rodrigo S. M., que invade o texto com sua consciência torturada, dilacerada por dúvidas e oscilações" (ROCHA, 2003, p. 50). Nesse processo metalinguístico, ocorre um movimento oscilatório de identificação/desidentificação do narrador com seu objeto narrado, a datilógrafa Macabéa:

Agora não é confortável: para falar da moça tenho que não fazer a barba durante dias e adquirir olheiras escuras por dormir pouco, só cochilar de pura exaustão, sou um trabalhador manual. Além de vestirme com roupa velha rasgada. Tudo isso para me pôr ao nível da nordestina. Sabendo no entanto que talvez eu tivesse que me apresentar de modo mais convincente às sociedades que muito reclamam de quem está neste instante mesmo batendo à máquina (LISPECTOR, 1998a, p. 19-20, grifo nosso).

Observe-se a ambiguidade que se instala no final do trecho destacado, reforçando a identificação do criador com sua criação: quem estaria "batendo à máquina"? O escritor Rodrigo S. M. ou a datilógrafa Macabéa? Conforme o conceito definido por

5 A paixão segundo G.H. (1964); A legião estrangeira (1964); Uma aprendizagem ou o livro dos prazeres (LISPECTOR, 1969/1998d); Felicidade clandestina ((LISPECTOR, 1971/1998c); Água viva ((LISPECTOR, 1973/1980); A imitação da rosa (1973); A via crucis do corpo (1974); Onde estivestes de noite (1974); A hora da estrela (1977).

6 O crescimento econômico acelerado do governo Médici, o chamado "Milagre Brasileiro", beneficiava as camadas mais privilegiadas da sociedade, promovendo uma alta concentração de renda e o aumento da pobreza entre os camponeses e a massa trabalhadora urbana, sistematicamente submetida ao "arrocho salarial" e excluída sumariamente da "repartição do bolo". 
Aristóteles em sua Ars poetica, a catarse, ou o prazer dos afetos, seria a finalidade última de toda obra de arte, envolvendo o espectador em um processo de identificação-desidentificação-purgação que, segundo Jauss (1979, p. 81), é "capaz de conduzir o ouvinte e o espectador tanto à transformação de suas convicções, quanto à liberação de sua psique."

Em $A H E$, Rodrigo S. M., ao mesmo tempo criador, ouvinte e espectador de Macabéa, passa por um processo catártico que mistura identificação e desidentificação do narrador/escritor com sua personagem. Assim, após "adquirir olheiras escuras" e "vestir-se com roupa velha rasgada", Rodrigo S. M. rejeita por completo a identificação inicial:

Ela me incomoda tanto que fiquei oco. Estou oco desta moça. E ela tanto mais me incomoda quanto menos reclama. Estou com raiva. Uma cólera de derrubar copos e quebrar vidraças. Como me vingar? Ou melhor, como me compensar? Já sei: amando meu cão que tem mais comida do que a moça. Por que ela não reage? Cadê um pouco de fibra? Não, ela é doce e obediente (LISPECTOR, 1998a, p. 26).

Em seguida à "desidentificação" com a nordestina, e igualmente suspenso entre parênteses, surge um certo sentimento de temor de Rodrigo S. M. de estar no lugar de Macabéa:

Quando penso que eu poderia ter nascido ela - e por que não? - estremeço. E parece-me covarde fuga de eu não ser, sinto culpa como disse num dos títulos (LISPECTOR, 1998a, p. 38)

Esse sentimento vem seguido de alguma piedade pela nordestina: "Ah pudesse eu pegar Macabéa, dar-lhe um bom banho, um prato de sopa quente, um beijo na testa enquanto a cobria com um cobertor. E fazer que quando ela acordasse encontrasse simplesmente o grande luxo de viver" (LISPECTOR, 1998a, p. 59). Após a morte de Macabéa, ocorre a total liberação da psique do narrador ao final da narrativa, com a consequente retomada de sua própria identidade: "E agora-agora só me resta acender um cigarro e ir para casa. Meu Deus, só agora me lembrei que a gente morre. Mas mas eu também?! / Não esquecer que por enquanto é tempo de morangos. / Sim" (LISPECTOR, 1998a, p. 87).

Observa-se, assim, que o emprego da metalinguagem, em $A H E$, faz-se acompanhado de um procedimento catártico que, operado pelo escritor/narrador Rodrigo S. M. em relação à sua personagem Macabéa, teria por objetivo reconhecer sua obra enquanto ficção que não pretende ser mera "cópia do real", como a literatura realista do século XIX ou a literatura "hiper-realista" da atualidade, mas que tem a realidade - tanto a do escritor quanto a do objeto narrado - como sua matéria e seu objetivo:

E eis que fiquei agora receoso quando pus palavras sobre a nordestina. E a pergunta é: como escrevo? Verifico que escrevo de ouvido assim como aprendi inglês e francês de ouvido. Antecedentes do meu escrever? sou um homem que tem mais dinheiro do que os que passam fome, o que faz de mim de algum modo um desonesto. E só minto na hora exata da mentira. Mas quando escrevo não minto. Que mais? Sim, não tenho classe social, marginalizado que sou. A classe alta me tem como um monstro esquisito, a média com desconfiança de que eu possa desequilibrá-la, a classe baixa nunca vem a mim. / Não, não é fácil escrever. É duro como quebrar rochas. Mas voam faíscas e lascas como aços espelhados (LISPECTOR, 1998a, p. 18-9).

\section{O pastiche}

Embora não seja um procedimento usual na escritura clariceana, o emprego do pastiche pode ser percebido em alguns contos da coletânea feita "sob encomenda" A via crucis do corpo (1974), em que não faltam ingredientes mórbidos, como incestos e crimes diversos, que recheiam as histórias à moda das peças de Nelson Rodrigues. Porém, enquanto na obra do "anjo pornográfico", introdutor do modernismo no teatro brasileiro, esses elementos psicopatológicos são levados a sério, nos contos clariceanos o que sobressai é a ironia, equilibrada com iguais doses de comicidade e humor negro, como pode ser observado no final do conto "O corpo": 
Na semana seguinte o secretário [de Xavier] foi à Polícia. Com Polícia não se brinca. Antes os policiais não quiserem dar crédito à história. Mas, diante da insistência do secretário, resolveram preguiçosamente dar ordem de busca na casa do polígamo. Tudo em vão: nada de Xavier. / Então Carmem falou assim: / — Xavier está no jardim. / — No jardim? fazendo o quê? / - Só Deus sabe o quê. / — Mas nós não vimos nada nem ninguém. / Foram ao jardim [...]. Então Beatriz, sem uma lágrima nos olhos, mostrou-lhes a cova florida. Três homens abriram a cova, destroçando o pé de rosas que sofriam à toa a brutalidade humana. / E viram Xavier. Estava horrível, deformado, já meio roído, de olhos abertos. / - E agora? Disse um dos policiais. / - E agora é prender as duas mulheres. / - Mas, disse Carmem, que seja numa mesma cela. I - Olhe, disse um dos policiais diante do secretário atônito, o melhor é fingir que nada aconteceu senão vai dar muito barulho, muito papel escrito, muita falação. / - Vocês duas, disse o policial, arrumem as malas e vão viver em Montevidéu. Não nos dêem maior amolação. / As duas disseram: muito obrigada. / E Xavier não disse nada. Nada havia mesmo a dizer (LISPECTOR, 1998b, p. 27-28).

Em AHE, Clarice Lispector elabora, com a indispensável ajuda do narrador/escritor Rodrigo S. M., um pastiche de velhos livros de literatura regionalista que, conforme observa Rogério Silva Pereira (2008, p. 293), tomou a si, em certo momento do Modernismo brasileiro, a tarefa de "narrar" o sertanejo, como modo de falar em nome do "excluído social": "nestes termos, o sertão foi construído pela literatura, mais do que representado". Assim, ao trazer à cena as figuras dos "retirantes" Macabéa e Olímpico de Jesus, Clarice Lispector faz uma paródia da tradicional literatura regionalista brasileira, ao mesmo tempo em que insere os seus personagens numa realidade cruel e palpável - a realidade da dura migração para a cidade grande, hostil e pouco familiar: "Depois - ignora-se por quê - tinham vindo para o Rio, o inacreditável Rio de Janeiro, a tia lhe arranjara emprego, finalmente morrera e ela, agora sozinha, morava numa vaga de quarto compartilhado com mais quatro moças balconistas das Lojas Americanas" (LISPECTOR, 1998a, p. 30).

Com efeito, Macabéa e Olímpico de Jesus não são somente "tipos" retirados da literatura regionalista, mas representam a própria desconstrução dessa vertente da literatura brasileira. Inaugurada no Romantismo oitocentista, com O sertanejo, de José de Alencar, a literatura regionalista teria tido como primeira "missão" a tarefa de incluir o sertanejo na "nacionalidade brasileira", como se vê também em Os sertões, de Euclides da Cunha. Esse autor, considerado "pré-modernista", revelou ao país os "desconhecidos singulares" do sertão, "assumindo a tarefa de contribuir, sob os mais variados ângulos, para o conhecimento da terra e do homem sertanejos" (ROCHA, 2003, p. 54). No Modernismo brasileiro, a tarefa da literatura regionalista, como chama a atenção Rogério Silva Pereira (2008, p. 294), passaria a ser a de tentar promover a inserção do sertanejo no ideal republicano, ao qual aderiu Graciliano Ramos. Porém, enquanto em Vidas secas Sinhá Vitória e Fabiano, apesar das circunstâncias adversas ao extremo, são protótipos de sertanejos que mantêm sua dignidade apesar dos pesares, Macabéa e Olímpico de Jesus são apresentados como uma espécie de "anti-heróis", reunindo em si características essencialmente negativas:

Não sentia a espingarda, o saco, as pedras miúdas que lhe entravam nas alpercatas, o cheiro de carniças que empestavam o caminho. As palavras de sinha (sic) Vitória encantavam-no. Iriam para diante, alcançariam uma terra desconhecida. Fabiano estava contente e acreditava nessa terra, porque não sabia como ela era nem onde era. Repetia docilmente as palavras de sinha Vitória, as palavras que sinha Vitória murmurava porque tinha confiança nele. E andavam para o sul, metidos naquele sonho. Uma cidade grande, cheia de pessoas fortes. Os meninos em escolas, aprendendo coisas difíceis e necessárias. Eles dois velhinhos, acabando-se como uns cachorros, inúteis, acabandose como Baleia. Que iriam fazer? Retardaram-se, temerosos. Chegariam a uma terra desconhecida e civilizada, ficariam presos nela. E o sertão continuaria a mandar gente para lá. O sertão mandaria para a cidade homens fortes, brutos, como Fabiano, sinha Vitória e os dois meninos (RAMOS, 2009, p. 127-128).

Ela [Macabéa] nascera com maus antecedentes e agora parecia uma filha de não-sei-o-quê com ar de se desculpar por ocupar espaço. No espelho distraidamente examinou de perto as manchas do rosto. Em Alagoas chamavam-se "panos", diziam que vinham do fígado. Disfarçava os panos com grossa camada de pó branco e se ficava meio caiada era melhor que o pardacento. Ela toda era um pouco encardida pois raramente se lavava. De dia usava saia 
e blusa, de noite dormia de combinação. Uma colega de quarto não sabia como avisar-lhe que seu cheiro era murrinhento (LISPECTOR, 1998a, p. 49).

Vinha [Olímpico] do sertão da Paraíba e tinha uma resistência que provinha da paixão por sua terra braba e rachada pela seca. Trouxera consigo, comprada no mercado da Paraíba, uma lata de vaselina perfumada e um pente, como posse sua e exclusiva. Besuntava o cabelo até encharcá-lo. Não desconfiava que as cariocas tinham nojo daquela meladeira gordurosa. Nascera crestado e duro que nem galho seco de árvore ou pedra ao sol. Era mais passível de salvação que Macabéa pois não fora à toa que matara um homem no sertão, o canivete comprido entrando mole-mole no fígado macio do sertanejo. [...] Olímpico pelo menos roubava sempre que podia [...]. Ter matado e roubar faziam com que ele não fosse um simples acontecido qualquer, davam-lhe uma categoria, faziam dele um homem com honra já lavada (LISPECTOR, 1998a, p. 57-58).

Ao lançar mão de "tipos" nordestinos estereotipados ao extremo, a escritora parece aproximar-se ainda do conceito de "cinema ideogramático" - chave para a compreensão da "Estética da Fome", de Glauber Rocha, que se tornou, ao lado do lema "uma câmera na mão e uma ideia na cabeça", uma espécie de manifesto do Cinema Novo. ${ }^{7}$ Segundo esse conceito, os elementos da cultura épico-popular dos cantadores, a oralidade, a literatura de cordel, as crenças e o misticismo popular devem ser apropriados criticamente pelo cinema para a recriação de uma nova linguagem que funcione como frente de resistência, ainda que pacífica e inconsciente, aos valores do "imperialismo cultural" e econômico. Voltado para a crítica social e para a luta do cinema latino-americano frente ao monopólio exercido pelo cinema norte-americano, o Cinema Novo objetivava denunciar ainda a precariedade das próprias condições de produção do cinema na América Latina, propondo assim uma reflexão acerca do subdesenvolvimento econômico, social e cultural em que se encontravam os então chamados "países do Terceiro Mundo".

Problematizando, pois, a relação entre estética e política no contexto de uma economia dependente, o projeto estético de Glauber Rocha define o cinema como "épico e sagrado, dialético, produto brasileiro típico que encontra sua matéria-prima bruta na cultura popular do Nordeste, ligado ao projeto estético-político de descolonização" (ROCHA, 1963, p. 14). No entanto, essa cultura popular, vista por Glauber como espécie de "guardiã" dos valores tradicionais, que resistem à colonização imperialista, não é, porém, capaz de promover, de fato, uma ação política, residindo aí, para o cineasta, todo o "impasse" e a "impossibilidade" do Terceiro Mundo. Assim, o "destino" do povo brasileiro atrelar-se-ia irremediavelmente ao colonizador, que conduz a cultura e a economia subdesenvolvidas. Essa perspectiva pessimista do cinema de Glauber Rocha se acha presente em filmes como Deus e o Diabo na Terra do Sol (ROCHA, 1964) e Terra em Transe (1967), em que o povo é visto como símbolo de um Brasil inculto e faminto, eternamente excluído dos benefícios da modernidade.

Na literatura clariceana, os sertanejos Macabéa e Olímpico de Jesus, "que por força das circunstâncias eram seres meio abstratos", e "que eram de algum modo inocentes e pouca sombra faziam no chão" (LISPECTOR, 1998a, p. 57-47), provocam o mesmo tipo de estranhamento almejado pelo cinema de Glauber Rocha, que tem como finalidade a conscientização e a reflexão. Porém, enquanto o cineasta considera a cultura popular nordestina como "frente de resistência", ainda que pacífica, ao imperialismo econômico, social e cultural exercido sobre os países do "Terceiro Mundo", em AHE, Macabéa não é apenas impotente para combater tal imperialismo. Ela é completamente tragada por

\footnotetext{
7 Surgido na década de 1950 no Brasil, o movimento do Cinema Novo propõe um novo modo de se fazer cinema, contrário tanto ao "udigrudi" do cinema norte-americano quanto às produções independentes das "chanchadas". O filme Rio, 40 graus (1955), de Nelson Pereira dos Santos, é considerado o fundador do Cinema Novo, que também teve nomes como Cacá Diegues, Leon Hirszman e Ruy Guerra, além de Glauber Rocha, espécie de "mentor intelectual” do movimento.
} 
ele, representado, no texto, pelo refrigerante de coca que "patrocina" a narrativa e pelo "Mercedes do imperialismo" (Rogério Silva Pereira) que a atropela no final:

[a narrativa] é escrita sob o patrocínio do refrigerante mais popular do mundo e que nem por isso me paga nada, refrigerante esse espalhado por todos os países. Aliás foi ele quem patrocinou o último terremoto na Guatemala. Apesar de ter cheiro de esmalte de unhas, de sabão Aristolino e plástico mastigado. Tudo isso não impede que todos o amem com servilidade e subserviência (LISPECTOR, 1998a, p. 23).

Então ao dar o passo de descida da calçada para atravessar a rua, o Destino (explosão) sussurrou veloz e guloso: é agora, é já, chegou a minha vez! / E enorme como um transatlântico o Mercedes amarelo pegou-a - e neste mesmo instante em algum único lugar do mundo um cavalo como resposta empinou-se em gargalhada de relincho (LISPECTOR, 1998a, p. 79).

Em $A H E$, o emprego do pastiche remete sim à literatura regionalista, mas somente para extrairthe os personagens de modo estereotipado. O seu objetivo é, antes, o de valer-se de tipos emblemáticos do "Brasil atrasado do sertão", eternamente em oposição ao "Brasil moderno do litoral", não somente para denunciar essa realidade, mas, sobretudo, para levar o leitor a uma reflexão perante a própria realidade narrada, transmutada em "universo ficcional", que remete diretamente ao ofício do escritor. Assim, $A H E$, o "livro mais social" de Clarice Lispector, apresenta uma dupla e indissociável face, oscilando entre a introspecção característica das obras anteriores e o novo ponto de vista adotado - a denúncia social; entre o intimismo autoquestionador do narrador/escritor Rodrigo S. M. diante do seu solitário processo de escrever e o "efeito distanciamento", que leva à reflexão, provocado quando o leitor se depara com a figura de Macabea.

\section{Nas Entrelinhas de um Diálogo com o Contexto Histórico}

Enquanto Clarice Lispector escrevia $A H E$, entre 1976 e 1977, vivia-se, no Brasil, uma crise econômica causada pelo "choque do petróleo" em 1974, que pôs fim à euforia do "Milagre Brasileiro", ao passo que, no campo político, os "sinceros esforços" (GEISEL apud SKIDMORE, 2004, p. 321) do presidente Geisel para dar início à prometida abertura política estavam longe de se concretizar. Ao contrário: embora o terrível AI-5 tenha sido extinto em dezembro de 1978, o governo Geisel (19741979) caracterizou-se por um recrudescimento da ditadura, orquestrado pelos militares da chamada "linha-dura", que teve episódios tenebrosos, como o assassinato do jornalista Vladimir Herzog em 25/10/1975, no DOI-CODI, em São Paulo, e a morte suspeita da estilista Zuzu Angel, ${ }^{8}$ em 14/04/1976, em um acidente de carro no Rio de Janeiro. Eram frequentes os "desaparecimentos" de pessoas e a deportação de políticos, artistas e intelectuais que se opunham ao regime militar. Jornais e pasquins foram retirados de circulação, enquanto jornalistas eram presos e torturados. A literatura que, antes, tinha sido "porta-voz" dos problemas sociais e políticos, foi definitivamente amordaçada: em 1976, os livros Feliz Ano Novo, de Rubem Fonseca, e Zero, de Ignácio de Loyola Brandão, publicados no ano anterior, foram recolhidos pelos órgãos da censura militarista. Como corolário desse estado de coisas, o Congresso Nacional foi fechado pelo chamado "Pacote de Abril", de 13/04/1977, pondo fim aos últimos resquícios de democracia no país e inaugurando a era dos "senadores biônicos".

Em $A H E$, não se encontra, a rigor, nenhuma referência a esse contexto histórico. No entanto, a

\footnotetext{
8 Zuzu Angel era mãe do jovem estudante guerrilheiro Stuart Jones, líder do MR-8, assassinado com requintes de crueldade pela ditadura militar em maio de 1971. A estilista sempre protestou contra o silêncio da ditadura sobre a morte do filho, e deixou uma declaração afirmando que o governo planejava matá-la (SKIDMORE, 2004, p. 241).
} 
Rádio Relógio de "cultura, notícias e a hora certa diretamente do Observatório Nacional, 24 horas no ar", (RIBEIRO, 2008) informada a cada minuto pela voz da locutora Íris Lettieri, que fez sucesso na década de 1970, é mencionada explicitamente no livro - cujo título parece remeter, ainda que de modo apenas velado, às estrelas que "enfeitam" as patentes dos militares, então alçados ao poder. Em suas noites solitárias, insone, cercada pelos corpos adormecidos das outras moças com quem dividia o quarto, Macabéa escuta a Rádio Relógio e, assim, aprende que "o Imperador Carlos Magno era chamado na terra dele de Carolus [...] e que a mosca voa tão depressa que se voasse em linha reta ela ia passar pelo mundo todo em 28 dias." (LISPECTOR, 1998a, p. 56).

A Rádio Relógio, assim como os demais meios de comunicação do período, caracteriza-se essencialmente pela "falta", ou seja, pela ausência de informação real sobre o difícil contexto político em que se encontrava o país, oferecendo "hora certa" e cultura pasteurizada, dirigida às massas incultas. Numa época de silêncio imposto aos meios de comunicação, prevaleciam, na programação televisiva, os "enlatados" norte-americanos, os programas de calouros, as transmissões de concursos de Miss e a exibição de telenovelas, que começavam a se firmar como indústria de passatempo dirigido às massas. Dramaturgos do teatro revolucionário do CPC ou com forte engajamento político "foram cooptados para garantir a evolução do gênero [de telenovelas]: Dias Gomes, Gianfrancesco Guarnieri, Lauro Cesar Muniz, Bráulio Pedroso e Oduvaldo Viana Filho (Vianinha), entre outros" (COSTA, 2000, p. 70).

Macabéa, porém, não se nutre apenas da "cultura" da Rádio Relógio, mas também das rememorações de um passado vivido no seio da cultura nordestina, que ela compartilha com Olímpico de Jesus. Suas ininteligíveis conversas eram sobre farinha, rapadura, carne-de-sol, melado, "pois esse era o passado de ambos e eles esqueciam o amargor da infância porque esta, já que passou, é sempre acre- doce e dá até nostalgia" (LISPECTOR, 1998a, p. 47). Entre as rememorações de Macabéa, encontrase a referência a um poço, que irá servir de mote a um dos diálogos absurdos entre ela e o namorado:

\begin{abstract}
Em pequena ela vira uma casa pintada de rosa e branco com um quintal onde havia um poço com cacimba e tudo. Era bom olhar para dentro. Então seu ideal transformara-se nisso: em vir a ter um poço só para ela. Mas não sabia como fazer e então perguntou a Olímpico: / - Você sabe se a gente pode comprar um buraco? / - Olhe, você não reparou até agora, não desconfiou que tudo que você pergunta não tem resposta? / Ela ficou de cabeça inclinada para o ombro assim como uma pomba fica triste (LISPECTOR, 1998a, p. 49).
\end{abstract}

$\mathrm{Na}$ literatura mundial, também se encontra um "poço" bastante conhecido. Em $O$ pequeno príncipe, o piloto e o menino caminham durante toda a noite pelo deserto, sedentos e febris à procura de um poço, ocasião em que o narrador rememora: "Quando eu era pequeno, habitava uma casa antiga, e diziam as lendas que ali fora enterrado um tesouro. Ninguém, jamais, conseguiu descobri-lo, nem talvez mesmo o tenha procurado. Mas ele encantava a casa toda. Minha casa escondia um tesouro no fundo do coração...”. Finalmente, pela manhã, encontram o poço: "O poço a que tínhamos chegado não se parecia de forma alguma com os poços do Saara. Os poços do Saara são simples buracos na areia. Aquele parecia um poço de aldeia. Mas não havia aldeia alguma, e eu julgava sonhar" (SAINT-EXUPÉRY, 2004, p. 110).

Citações um tanto reducionistas, como "o coração vê mais longe que os olhos", "tu te tornas eternamente responsável por aquilo que cativas", e ainda "o que torna belo o deserto é que ele esconde um poço em algum lugar”, extraídas d'O pequeno príncipe, tornaram-se populares na década de 1970 no Brasil, quando o livro de Saint-Exupéry era "leitura obrigatória" entre as candidatas dos famosos concursos de "miss". No texto clariceano, o "poço" sem dúvida suscita interpretações de caráter intimista, ligadas ao subconsciente, ao "interior" da personagem ("Era bom olhar para dentro"), mas pode igualmente ser visto como referência velada 
e profundamente irônica a um contexto em que, nos seus subterrâneos, não esconde poços capazes de aliviar a "sede do coração", mas sim as dores de uma sociedade que, contraditoriamente, exporta as alegrias do futebol e tem, nas figuras sempre sorridentes de "Suas Majestades" - os Reis Roberto Carlos e Pelé - a sua maior expressão de felicidade. Em Clarice Lispector, a felicidade, quando existe, só pode ser "clandestina". Ou, como diz o narrador/ escritor Rodrigo S. M.: "Felicidade? Nunca vi palavra mais doida, inventada pelas nordestinas que andam por aí aos montes" (LISPECTOR, 1998a, p. 12).

\section{Conclusão}

Embora não apresente marcas visíveis de diálogo com o contexto histórico brasileiro, não se pode afirmar que a obra clariceana não dialogue com o contexto a que pertence. $\mathrm{O}$ intimismo, a introspecção e as questões filosófico-existenciais, que se tornaram a "marca por excelência" da escrita clariceana e estão fortemente presentes em textos como A paixão segundo G. H. (1964), Uma aprendizagem ou o livro dos prazeres (LISPECTOR, 1969/1998d) e Água viva (1973), revelam possuir influências típicas do contexto do pós-guerra, dominado pelo existencialismo de Sartre e Camus, voltado para uma concepção de indivíduo essencialmente diferente daquela forjada pelo Romantismo do século XIX.

Conforme observa Georg Simmel, o movimento romântico oitocentista, sobretudo na Alemanha, considerando que a Humanidade estaria representada de forma peculiar em cada homem, forjou a noção de indivíduo como uma unidade singular, insubstituível e incomparável (SIMMEL, 1986, p. 260). No pós-guerra, ao contrário, o que existe é um "sujeito despedaçado", atormentado por questões insolúveis, como se vê em O mito de Sísifo, de Camus (1943), e no chamado "Teatro do Absurdo" de Samuel Beckett, Ionesco, Adamov e Genet, entre outros dramaturgos, que expressaram em suas peças a falta de objetivo, as ações sem sentido, absurdas e inúteis que parecem mover o homem perdido num mundo subitamente desprovido de valores religiosos, metafísicos e transcendentais: o mundo do pós-guerra (ESSLIN, 1968, p. 20).

Nessa perspectiva, AHE dá continuidade às obras anteriores de Clarice Lispector, apresentando características típicas da literatura do pós-guerra e trabalhando com elementos existencialistas, como o "absurdo" - quer de Sartre, Beckett ou Camus -, de modo original. Neste sentido, Macabéa revelase essencialmente uma "personagem absurda", ao carregar em si a vivência do absurdo e não meramente o discurso sobre o absurdo. Observe-se, ainda, que os diálogos non sense entre Macabéa e Olímpico de Jesus encontram paralelo nas "peças sem enredo" de Samuel Beckett, como em Esperando Godot, onde "não acontece nada, ninguém vem, ninguém vai, é horrível" (BECKETT apud ESSLIN, 1968, p. 39), a não ser a angustiante espera dos dois vagabundos, Vladimir e Estragon, por certo Godot, que nunca vem. Da mesma forma, os encontros de Macabéa e Olímpico são permeados por diálogos "absurdos", emoldurados por nenhum acontecimento: "Enfim, o que fosse acontecer, aconteceria. E por enquanto nada acontecia, os dois não sabiam inventar acontecimentos." (LISPECTOR, 1998a, p. 47).

A "absurda" imposição do silêncio, gerada num contexto de ditadura militar, parece refletirse na personagem: Macabéa mal sabe sobre palavras, necessita de alguém que fale por ela, já que "ela falava, sim, mas era extremamente muda" (LISPECTOR, 1998a, p. 29). Desse modo, Rodrigo S. M. - cujas iniciais os estudiosos acreditam ser abreviação de "Sua Majestade", numa referência irônica ao papel do escritor e à classe social a que pertence - toma a si a tarefa de "gritar" por ela, pois "é minha obrigação contar sobre essa moça entre milhares delas. E dever meu, nem que seja de pouca arte, o de reverlar-lhe a vida./ Porque há o direito ao grito./ Então eu grito" (LISPECTOR, 1998a, p. 13). No entanto, verifica-se que esse "grito" seja dado por um membro da elite, que vê sua personagem pelas lentes do preconceito. 
AHE, ao contar a história de Macabéa, não o faz por meio de um narrador onisciente e onipresente, alheio ao objeto narrado, mas sim pelo olhar inquieto e inquiridor de Rodrigo S. M., um "eu empírico autoral" (COSTA LIMA, 1986) cuja condição social e valores pessoais podem ser percebidos pelos seus hábitos refinados e "dispensáveis" - como "beber vinho branco gelado" e "bater à máquina às três horas da tarde", em flagrante oposição/conflito com a realidade de sua personagem. Desse modo, ao afirmar que "tudo isso, sim, a história é história. Mas sabendo antes para nunca esquecer que a palavra é fruto da palavra. A palavra tem que se parecer com a palavra" (LISPECTOR, 1998a, p. 20), o texto clariceano assume seu caráter de ficção - "história da história" -, que depende do uso deliberado da palavra por alguém que a escreve: o escritor.

Assim, paralelamente à problemática da exclusão social da "nordestina" Macabéa, Clarice Lispector trata, em AHE, do ofício do escritor, expondo as dificuldades da tarefa de narrar num país em que o intelectual é, ainda hoje em dia, visto como pertencente a uma "elite" social e econômica, pouco envolvido com a realidade concreta, que lhe serviria tão somente de "inspiração" - surgida, quem sabe, num "momento epifânico". A postura de Clarice Lispector revela-se idêntica à de Glauber Rocha que, com seus filmes "peliculamente incorretos", buscava denunciar não somente a carência social e econômica do Brasil-sertão, mas também a precariedade das condições de produção enfrentada pelos cineastas latino-americanos, engolidos pelo "império colonizador".

No cinema de Glauber Rocha, a "quarta parede" do cinema naturalista, que isola a cena do espectador, é quebrada no filme Terra em Transe (1967), quando os atores olham diretamente para a câmera, estabelecendo assim uma ligação com o espectador, cujo objetivo é a conscientização e a reflexão. De modo análogo, a metalinguagem clariceana buscaria quebrar a "quarta parede" da literatura realista, fugindo a um encarceramento puramente literário, num movimento essencialmente paradoxal, que se assume como ficção para questionar a própria elaboração ficcional. Adicionalmente, em AHE, observa-se a utilização da palavra - a matéria-prima por excelência do escritor - para levar o leitor a uma reflexão sobre a ausência da palavra, numa época em que, "por força de lei" (LISPECTOR, 1998a, p. 18), a palavra - o grito - devia ser silenciada/o. Clarice Lispector certamente não encena a História em A hora da estrela. Mas, formada de instantes mínimos, a curta "história da história" de Macabéa faz contracenar a "história dos vencidos" (Walter Benjamin) na ficção clariceana.

\section{Referências}

ABIAHY, A. C. A. Os contos de Clarice Lispector problematizando um 'novo' perfil de mulher. In: GOMES, A. L. (Org.). Seminário Internacional Clarice em Cena30 Anos Depois. Brasília: UnB, 2008, p. 29-37.

ADORNO, T. W. A indústria cultural. Belo Horizonte: FAFICH/UFMG, 1985. Mimeo.

BARBIERI, T. Ficção impura: prosa brasileira dos anos 70, 80, 90. Rio de Janeiro: EdUERJ, 2003.

CAMPEDELLI, S. Y;; ABDALA JUNIOR, B. Clarice Lispector: seleção de textos, notas, estudos biográfico, histórico e crítico e exercícios. São Paulo: Abril Educação, 1981.

CAMUS, A.. O mito de Sísifo: ensaio sobre o absurdo. Lisboa: Edição Livros do Brasil, 1943.

CÂNDIDO, A.. No raiar de Clarice Lispector. In: Vários escritos. São Paulo: Duas Cidades, 1977. p. 123131.

COSTA LIMA, L. Documento e nacionalidade no Brasil: o superego europeu e a domesticação do ficcional. In: . Sociedade e discurso ficcional. Rio de Janeiro: Guanabara, 1986. p. 230-239.

COSTA, C. Eu compro essa mulher: romance e consumo nas telenovelas brasileiras e mexicanas. Rio de Janeiro: Jorge Zahar, 2000.

COUTINHO, A. (Dir.). A literatura no Brasil. Rio de Janeiro: José Olympio, 1986.

ESSLIN, M. O teatro do absurdo. Rio de Janeiro: Jorge Zahar, 1968. 
FRANCO JR. A. O projeto literário de Clarice Lispector em A via crucis do corpo. In: GOMES, A.L. (Org.). Seminário Internacional Clarice em Cena-30 Anos Depois. Brasília: UnB, 2008, p. 41-46.

GOMES, A. L. (Org.). Seminário Internacional Clarice em Cena--30 Anos Depois. Brasília: UnB, 2008.

JAUSS, H.-R.. A história da literatura como provocação à teoria literária. São Paulo: Ática, 1994.

O prazer estético e as experiências fundamentais da poiesis, aisthesis e kártasis. In: COSTA LIMA, Luiz (Org.). A literatura e o leitor. Rio de Janeiro: Paz e Terra, 1979. p. 43-82.

LIMA M. E. S.. Clarice Lispector e Alice Ferney: afinidades e dissonâncias de um encontro amoroso. 2008. Dissertação (Mestrado) - Universidade de São Paulo, São Paulo.

LISPECTOR, C. A hora da estrela. Rio de Janeiro: Rocco, 1998a.

1998b.

A via crucis do corpo. Rio de Janeiro: Rocco,

Água viva. 5. ed. Rio de Janeiro: Nova Fronteira, 1980.

Felicidade clandestina. Rio de Janeiro: Rocco, 1998c.

Laços de família. 12. ed. Rio de Janeiro: Nova Fronteira, 1983.

Perto do coração selvagem. Rio de Janeiro: Francisco Alves, 1990.

Uma aprendizagem ou o livro dos prazeres. Rio de Janeiro: Rocco, 1998d.

PEREIRA, R. S. A hora da estrela: crise da narrativa no Modernimos e na contemporaneidade. In: GOMES, A. L. (Org.). Seminário Internacional Clarice em Cena-30 Anos Depois. Brasília: UnB, 2008, p. 291-300

RAMOS, G. Vidas secas: Posfácio de Hermenegildo Bastos. 111. ed. Rio de Janeiro: Record, 2009.

RIBEIRO, C. A saudosa rádio relógio federal. 2008. Disponível em: <http://orebate-cassioribeiro.blogspot. com/2008/03/saudosa-rdio-relgio-federal.html $>$. Acesso em: 5 out. 2010.

ROCHA, F. C. D. A hora da estrela, de Clarice Lispector: singularidade e transgressão. In: (Org.). Literatura brasileira em foco. Rio de Janeiro: EdUerj, 2003. p. 4760 .

ROCHA, G. Deus e o diabo na terra do sol. Rio de Janeiro: Civilização Brasileira, 1964.
Revisão crítica do cinema brasileiro. Rio de Janeiro: Civilização Brasileira, 1963.

SÁ, O. A escritura de Clarice Lispector. Petrópolis: Vozes, 2000.

SAINT-EXUPÉRY, A. O pequeno príncipe. Tradução de Dom Marcos Barbosa. Rio de Janeiro: Agir, 2004.

SANT'ANNA, A. R. Análise estrutural do romance brasileiro. Petrópolis: Vozes, 1973.

. O ritual epifânico do texto. In: LISPECTOR, Clarice. A paixão segundo G. H. Brasília: CNPq, 1988. p. 237-257.

SIMMEL, G. El individuo y la libertad: ensayos de critica de la cultura. Barcelona: Península, 1986.

SKIDMORE, T. Brasil: de Castelo a Tancredo, 1964 a 1985. 8. ed. Rio de Janeiro: Paz e Terra, 2004.

SOUSA, R. B. A via-crúcis de GH: em busca da crítica social em Clarice Lispector. In: GOMES, A. L. (Org.). Seminário Internacional Clarice em Cena-30 Anos Depois. Brasília: UnB, 2008, p. 281-290.

SPINELLI, D. Notas sobre A hora da estrela", de Clarice Lispector. In: GOMES, A. L. (Org.). Seminário Internacional Clarice em Cena-30 Anos Depois. Brasília: UnB, 2008, p. 95-103.

VASCONCELLOS, M. H. F. A escrita intensiva de Clarice Lispector. In: GOMES, A. L. (Org.). Seminário Internacional Clarice em Cena-30 Anos Depois. Brasília: UnB, 2008.

VIANNA, S. T. W. Desenvolvimento econômico e reformas institucionais no Brasil: considerações sobre a construção interrompida. 2007. Tese (Doutorado em Economia) - Universidade Federal do Rio de Janeiro, Rio de Janeiro. Disponível em: $<$ http://www.ie.ufrj.br/ datacenterie/pdfs/pos/tesesdissertacoes/tese_salvador_ werneck.pdf $>$. Acesso em: 5 out. 2010.

VICENTINI. A. Clarice em processo. In: GOMES, A. L. (Org.). Seminário Internacional Clarice em Cena-30 Anos Depois. Brasília: UnB, 2008, p. 23-28.

Recebido em: dezembro de 2010 Aceito em: maio de 2011 
